\title{
Hubungan Pemberian ASI Eksklusif, Status Gizi, dan Kejadian Diare dengan Perkembangan Motorik pada 1000 Hari Pertama Kehidupan
}

\author{
Dahliansyah, ${ }^{*}$ Diffah Hanim, ${ }^{* *}$ Harsono Salimo ${ }^{* * *}$ \\ *Program Magister Ilmu Gizi, **Fakultas Kedokteran Bidang Ilmu Gizi, ***Bagian Ilmu Kesehatan Anak Fakultas Kedokteran \\ Universitas Sebelas Maret Rumah Sakit Dr. Moewardi, Surakarta
}

Latar belakang. Pemberian ASI tidak eksklusif dapat menyebabkan risiko kesehatan pada bayi, yaitu penyimpangan perkembangan motorik, serta kejadian diare. Gerakan $1000 \mathrm{HPK}$, ditujukan untuk mencegah malnutrisi dari awal kehamilan sampai anak usia 2 tahun. Tujuan. Penelitian ini untuk menganalisis hubungan pemberian ASI ekslusif, status gizi, dan kejadian diare dengan perkembangan motorik pada $1000 \mathrm{HPK}$.

Metode. Subjek penelitian adalah ibu yang memiliki anak baduta ( $\geq 6-24)$ bulan. Variabel dependen adalah perkembangan motorik, sedangkan independen adalah ASI eksklusif, status gizi, dan kejadian diare. Metode penelitian adalah observasional analitik dengan desain cross sectional. Jumlah subjek 138 baduta, usia z6-24 bulan dipilih secara porposive sampling. Data ASI eksklusif didapat dari buku KIA/KMS, status gizi dengan pengukuran antropometri, kejadian diare didapat berdasarkan wawancara langsung, dan data perkembangan motorik dengan kuesioner KPSP, kemudian dianalisis menggunakan uji Chi square dan Regresi Logistik.

Hasil. Terdapat hubungan bermakna antara pemberian ASI eksklusif selama periode 1000 HPK dengan perkembangan motorik baduta $(\geq 6-24)$ bulan $(\mathrm{OR}=0,45 ; \mathrm{IK} 95 \%=0,21-0,99 ; \mathrm{p}=0.046)$. Tidak terdapat hubungan antara status gizi selama periode $1000 \mathrm{HPK}$ dengan perkembangan motorik baduta $(\geq 6-24)$ bulan. Tidak terdapat hubungan antara kejadian diare selama periode 1000 HPK dengan perkembangan motorik baduta $(>6-24)$ bulan. Hasil analisis multivariat menunjukkan bahwa baduta $(\geq 6-24)$ bulan yang tidak diberi ASI eksklusif selama periode $1000 \mathrm{HPK}$, berisiko 0,45 kali mengalami gangguan perkembangan motorik.

Kesimpulan. Pemberian ASI eksklusif kepada baduta ( $\geq 6-24)$ bulan selama periode $1000 \mathrm{HPK}$, memengaruhi perkembangan motorik. Sari Pediatri 2018;20(2):70-8

Kata kunci: ASI eksklusif, status gizi, diare, perkembangan motorik

\section{The Relationship between Exclusive Breast Feeding, Nutrition Status and Diarrhea with Motor Development in The First 1000 Days of Life}

Dahliansyah, ${ }^{*}$ Diffah Hanim, ${ }^{* *}$ Harsono Salimo ${ }^{* * *}$

Background. Non exclusive Breast-feeding can cause health risks for infants, namely the risk of motor development, as well as the incidence of diarrhea. The First 1000 Days of Life Movement (HPK), globally aimed to prevent malnutrition from early pregnancy until the age of 2 years old.

Objectives. This study was to analyze the relationship of exclusive breastfeeding, nutritional status and diarrhea incidence with motor development in the first 1000 days of life (HPK).

Method. The subjects of this study were mothers who had children or in Indonesian called as baduta ( $\geq 6-24)$ months. The dependent variable was motor development, while the independent variables were exclusive breastfeeding, nutritional status, and diarrhea incidence. The observational analytic research using cross sectional design was used as the research method here. The number of subjects was 138 baduta (age of infant $\geq 6-24$ months which selected by purposive sampling). The data of exclusive breastfeeding were obtained from KIA / KMS books, the data of nutritional status were obtained through direct measurement of anthropometry. Diarrhea incidence data were obtained based on direct interview, and the data of motor development was taken with KPSP questionnaire, then it were analyzed using Chi square test and logistic regression.

Results. There was a significant relationship between exclusive breastfeeding during $1000 \mathrm{HPK}$ and motor development of baduta (infants whose ages were in $\geq 6-24$ months) with the value $(\mathrm{OR}=0,45 ; \mathrm{IK} 95 \%=0,21-0,99 ; \mathrm{p}=0.046)$. There was no relationship between nutritional status during $1000 \mathrm{HPK}$ period with the motor development of baduta ( $\geq 6-24)$ months. There was no relationship between diarrhea incidence during $1000 \mathrm{HPK}$ period and motor development of baduta ( $\geq 6-24$ months) with. The result of multivariate analysis showed that baduta ( $\geq 6-24)$ months were not exclusively breastfed during $1000 \mathrm{HPK}$ period, 0.45 times gets risk of motor development disorder.

Conclusion. Exclusive breastfeeding to baduta ( $\geq 6-24)$ months during the $1000 \mathrm{HPK}$ period has influence in their motor development. Sari Pediatri 2018;20(2):70-8

Keywords: exclusive breastfeeding, nutritional status, diarrhea, motor development

Alamat korespondensi: Dahliansyah, Program Studi Ilmu Gizi, Pascasarjana, Universitas Sebelas Maret, Jl. Ir. Sutami 36A, Surakarta 57126. Email: dablian_syah_gz@yahoo.co.id 
$\mathrm{P}$ ada anak usia kurang dari enam bulan, penggantian ASI dengan susu formula komersial, pengenalan cairan seperti air dan jus, suplementasi dan pengenalan makanan padat, semi padat, dan lembut berakibat buruk pada anak dan dapat menyebabkan prevalensi ASI eksklusif turun. ${ }^{1}$

Di negara berpenghasilan rendah dan menengah, $37 \%$ bayi usia 6 bulan memperoleh ASI eksklusif. ${ }^{2}$ Sebagai perbandingan, pemberian ASI saat lahir di Inggris dari tahun 2005 (63-78)\%, 21\% ibu memberikan ASI sampai usia 6 bulan. ${ }^{3}$ Rencana Strategis Kementerian Kesehatan Republik Indonesia 2015-2019, bayi <6 bulan harus mendapat ASI eksklusif 50,0\%. ${ }^{4}$ Data Riset Kesehatan Dasar tahun 2013, cakupan ASI eksklusif 30,2\%.5 Pemberian ASI eksklusif di Provinsi Kalimantan Barat tahun 2016 adalah 51,8\%. ${ }^{6}$ Data di Kota Pontianak, cakupan ASI eksklusif tahun 2015-2016 mengalami penurunan (80,14\% menjadi $73,1 \%$ di tahun 2016). ${ }^{7}$

Suatu studi kohort di Australia menyatakan bahwa pemberian ASI eksklusif jangka panjang berdampak pada kesehatan dan motorik anak. ${ }^{8}$ Triyani menyatakan bahwa pemberian ASI $<4$ bulan berisiko 7,325 kali lebih besar terjadi penyimpangan perkembangan dibandingkan pada anak yang memperoleh ASI >4 bulan. ${ }^{?}$

Periode 6-24 bulan adalah waktu yang paling penting bagi pertumbuhan. Malnutrisi dalam periode ini, disebabkan karena anak memiliki kebutuhan tinggi zat gizi dan ada kekurangan dalam kuantitas dan kualitas makanan yang disediakan, terutama saat selesai ASI eksklusif. ${ }^{10}$

Angka kematian bayi di Indonesia dan dunia setiap tahun dapat dicegah dengan pemberian ASI eksklusif. ${ }^{11}$ Balita yang tidak mendapat ASI eksklusif lebih berisiko mengalami penyakit infeksi. Pemberian ASI $<6$ bulan berpeluang lebih cepat terkena infeksi, terutama penyakit diare. ${ }^{12}$ Diare berkontribusi terhadap terjadinya kekurangan gizi, kehilangan elektrolit tubuh, dan malabsorpsi, serta gangguan pertumbuhan dan kejadian stunting pada anak. ${ }^{13,14}$

Gerakan Nasional percepatan perbaikan gizi atau dikenal dengan Gerakan 1000 Hari Pertama Kehidupan (HPK) adalah sebuah gerakan global sebagai upaya mencegah malnutrisi. ${ }^{15}$ Dimulai saat kehamilan sampai anak usia 2 tahun, khususnya terhadap penurunan indikator kejadian bayi berat lahir rendah (BBLR), balita pendek (stunting), kurus (wasting), gizi kurang (underweight). ${ }^{16}$ Periode 1000 HPK mendapatkan perhatian karena dapat berdampak positif terhadap perkembangan kognitif dan fisik anak. ${ }^{17}$

Berdasarkan profil data tahun 2016 prevalensi kejadian diare Kecamatan Pontianak Utara paling tinggi dibandingkan dengan 5 kecamatan lain, sebesar 37,3 per 1000 penduduk hidup. Data penduduk mendapat akses air minum layak $12,2 \%$, penduduk menggunakan air hujan sebagai sumber air minum sebesar 92,5\%. Status gizi tahun 2016 ditemukan balita dengan kategori status gizi buruk 8 orang $(27,6 \%)$, sedangkan stunting $16,6 \%$, jauh di bawah angka nasional $37,2 \%$. Kejadian wasting 11,5\%, masih dibawah angka nasional yang sebesar $12,1 \%$. Masih adanya masalah penurunan cakupan ASI eksklusif, penyakit diare dan gangguan gizi pada balita di Kecamatan Pontianak Utara, sehingga perlu dilihat keterkaitan masalah tersebut dengan kejadian perkembangan motorik baduta (6-24 bulan).

Peneliti tertarik meneliti di wilayah Kecamatan Pontianak Utara karena sebagian besar wilayahnya berada di aliran sungai Kapuas. Air bersih tergantung dari air sungai tersebut. Selain itu, kualitas air Kapuas tidak bisa dikonsumsi sebagai air minum sehingga masyarakat menggunakan air hujan sebagai sumber air minum. Apabila pengolahan air sungai tidak baik dapat menyebabkan diare. Tujuan penelitian ini untuk menganalisis hubungan pemberian ASI eksklusif, status gizi, dan kejadian diare dengan perkembangan motorik pada $1000 \mathrm{HPK}$

\section{Metode}

Subjek penelitian ini adalah ibu yang memiliki anak baduta ( $\geq 6-24)$ bulan dengan catatan lengkap (ANC, buku KIA, KMS ibu hamil dan KMA anak baduta). Lokasi penelitian di Kecamatan Pontianak Utara Propinsi Kalimantan Barat. Variabel dependen adalah perkembangan motorik, dan variabel independen adalah ASI eksklusif, status gizi, dan kejadian diare. Metode penelitian yang digunakan adalah observasional analitik dengan desain cross sectional. Jumlah subjek 138 baduta, usia $\geq 6-24$ bulan yang dipilih secara porposive sampling. Kriteria inklusi adalah baduta usia $\geq 6-24$ bulan memiliki KMS dan tidak dalam kondisi dirawat karena sakit serta tinggal di Kota Pontianak dibuktikan dengan memiliki kartu kelurga (KK) atau KTP. Kriteria eksklusi adalah baduta 
usia $>6-24$ bulan yang memilik penyakit bawaan, tidak tinggal dengan ibu kandung, memiliki kakak umur $<1$ tahun (sundulan).

Data variabel ASI eksklusif didapat dari buku KIA/KMS. Status gizi didapat melalui pengukuran langsung antropometri. Data kejadian diare didapat berdasarkan wawancara langsung. Data perkembangan motorik kasar dan halus diambil dengan kuesioner pra skrining perkembangan (KPSP). Kategori ASI eksklusif adalah ASI eksklusif dan tidak ASI eksklusif. Status gizi dikelompokkan menjadi pendek dan normal. Kategori kejadian diare adalah diare dan tidak diare. Sementara untuk variabel perkembangan motorik sesuai dan menyimpang. Kemudian data dianalisis menggunakan softwer SPSS versi 18 . Analisis bivariat digunakan uji Chi square. Analisis multivariat digunakan regresi logistik.

\section{Hasil}

Penelitian ini dilakukan kepada ibu yang memiliki baduta dengan rentang usia $\geq 6-24$ bulan. Jumlah sampel 138 ibu baduta usia $\geq 6-24$ bulan, 52\% berjenis kelamin laki-laki dan $47,8 \%$ perempuan. Berdasarkan umur subjek, lebih banyak kelompok umur 12-24 bulan (63,8\%), dibandingkan umur 6-11 bulan $(36,2 \%)$. Pendidikan ayah dan ibu lebih banyak tamat SMA/sederajat, dan masih ada yang tidak tamat sekolah dasar (SD). Pekerjaan ayah 51,4\% bekerja di antaranya, pekerja swasta, buruh, maupun kerja borongan. Waktu lahir subjek penelitian 92\% memiliki

Tabel 1. Karakteristik orang tua dan baduta

\begin{tabular}{lcc}
\hline Variabel & $\mathrm{n}$ & $\%$ \\
\hline Karakteristik baduta & & \\
Jenis kelamin & & \\
$\quad$ Laki-Laki & 72 & 52,2 \\
$\quad$ Perempuan & 66 & 47,8 \\
Umur (bulan) & & \\
$\quad$ 6-11 & 50 & 36,2 \\
$\quad$ 12-24 & 88 & 63,8 \\
$\quad$ Berat badan lahir (gram) & & \\
$\quad<2500$ & 11 & 8,0 \\
$\quad \geq 2500$ & 127 & 92,0 \\
Panjang badan lahir $(\mathrm{cm})$ & & \\
$\quad<48$ & 24 & 17,4 \\
$\quad \geq 48$ & 114 & 82,6 \\
\hline
\end{tabular}

\begin{tabular}{|c|c|c|}
\hline Variabel & $\mathrm{n}$ & $\%$ \\
\hline \multicolumn{3}{|c|}{ Cuci tangan sebelum makan } \\
\hline Ya & 108 & 78,3 \\
\hline Tidak & 30 & 21,7 \\
\hline \multicolumn{3}{|l|}{ Energi } \\
\hline Baik ( $\geq 70 \%$ AKG) & 31 & 22,5 \\
\hline Devisit (<70\% AKG) & 107 & 77,5 \\
\hline \multicolumn{3}{|l|}{ Protein } \\
\hline Baik ( $\geq 70 \%$ AKG) & 61 & 44,2 \\
\hline Devisit (<70\% AKG) & 77 & 55,8 \\
\hline \multicolumn{3}{|l|}{ Lemak } \\
\hline Baik ( $\geq 70 \%$ AKG) & 28 & 20,3 \\
\hline Devisit (<70\% AKG) & 110 & 79,7 \\
\hline \multicolumn{3}{|l|}{ Karbohidrat } \\
\hline Baik ( $\geq 70 \%$ AKG) & 7 & 5,07 \\
\hline Devisit (<70\% AKG) & 131 & 94,9 \\
\hline \multicolumn{3}{|l|}{ Karakteristik orang tua } \\
\hline \multicolumn{3}{|l|}{ Pendidikan ayah } \\
\hline Tidak tamat SD & 6 & 4,3 \\
\hline Tamat SD/sederajat & 28 & 20,3 \\
\hline Tamat SMP/sederajat & 31 & 22,5 \\
\hline Tamat SMA/sederajat & 61 & 46,4 \\
\hline Perguruan tinggi & 9 & 6,5 \\
\hline \multicolumn{3}{|l|}{ Pekerjaan ayah } \\
\hline PNS/POLRI/TNI & 4 & 2,9 \\
\hline Pegawai swasta & 46 & 33,3 \\
\hline Wirausaha & 13 & 9,4 \\
\hline Petani/nelayan & 4 & 2,9 \\
\hline Lainnya & 71 & 51,4 \\
\hline \multicolumn{3}{|l|}{ Pendidikan ibu } \\
\hline Tidak tamat SD & 8 & 5,8 \\
\hline Tamat SD/sederajat & 29 & 21,0 \\
\hline Tamat SMP/sederajat & 33 & 23,9 \\
\hline Tamat SMA/sederajat & 55 & 39,9 \\
\hline Perguruan tinggi & 13 & 9,4 \\
\hline Jumlah & 100 & 100 \\
\hline
\end{tabular}

berat badan $\geq 2.500$ gram. Subjek waktu lahir $82,6 \%$ memiliki panjang badan $\geq 48 \mathrm{~cm}$. Subjek melakukan inisiasi menyusu dini (IMD) waktu lahir 71,7\%. Baduta mencuci tangan sebelum makan 78,3\%. Hasil recall 24 jam terlihat bahwa kecukupan energi 77,5\% mengalami devisit atau kekurangan, sedangkan untuk protein $55,8 \%$ mengalami devisit, begitu juga lemak $79,7 \%$ mengalami devisit, dan untuk karbohidrat 94,9\% mengalami devisit. Gambaran karakteristik orang tua dan baduta tertera pada Tabel 1 .

Hasil uji Chi square menunjukkan bahwa ada 
hubungan yang signifikan $(\mathrm{p}=0,028)$ antara ASI eksklusif dengan perkembangan motorik baduta usia $\geq 6-24$ bulan pada $1000 \mathrm{HPK}$. Hasil uji Chi square menunjukkan tidak ada hubungan status gizi berdasarkan indeks $\mathrm{TB} / \mathrm{U}$ dengan perkembangan motorik ( $\mathrm{p}=0,240$ ). Hasil uji Chi square menunjukkan bahwa tidak ada hubungan yang signifikan $(\mathrm{p}=0,453)$ antara kejadian diare dengan perkembangan motorik baduta usia $\geq 6-24$ bulan. Adapun hasil lengkap analisis bivariat varibel penelitian tertera pada Tabel 2 berikut ini.

Berdasarkan hasil analisis pada Tabel 3, diketahui terdapat hubungan signifikan $(p<0,05)$ antara ASI eksklusif dengan perkembangan motorik. Baduta yang tidak ASI eksklusif selama 6 bulan memiliki peluang 0,45 kali mengalami gangguan perkembangan motorik dibandingkan dengan yang ASI eksklusif $(\mathrm{OR}=0,45$ IK95\%:0,21-0,99). Tidak terdapat hubungan signifikan antara status gizi dengan perkembangan motorik, tetapi anak yang status gizi normal berpeluang 2,45 kali mengalami perkembangan motorik sesuai. Tidak terdapat hubungan signifikan antara kejadian diare dengan perkembangan motorik, tetapi anak yang menderita diare berpeluang 1,56 kali mengalami perkembangan motorik menyimpang.

\section{Pembahasan}

Berdasarkan hasil penelitian, kami menemukan bahwa pemberian ASI berpengaruh terhadap perkembangan motorik kasar dan halus pada baduta. Hasil analisis regresi logistik mendapatkan bahwa baduta yang tidak diberikan ASI eksklusif selama 6 bulan memiliki peluang $0,45 \mathrm{kali}$ mengalami gangguan perkembangan motorik dibandingkan dengan yang diberi ASI eksklusif.

Sejalan dengan penelitian kami, Ali $\mathrm{dkk}^{18}$ dengan penelitian restrospektifnya, melaporkan bahwa pemberian ASI eksklusif berpengaruh positif pada perkembangan motorik balita. Sugeng $\mathrm{dkk}^{19}$ melaporkan bahwa terdapat hubungan antara lama pemberian ASI eksklusif dengan perkembangan anak usia 12-36 bulan. Alberto $\mathrm{dkk}^{20}$ juga melaporkan bahwa terdapat hubungan antara pemberian ASI eksklusif durasi dan skor tes dalam kosa kata.

Perkembangan motorik, daya ingat, dan kemampuan bahasa balita yang mendapat ASI eksklusif lebih tinggi dibandingkan susu formula. ${ }^{21}$ Pemberian ASI eksklusif selama 6 bulan pertama kehidupan dapat mendukung pertumbuhan dan perkembangan bayi. ${ }^{22}$ Bayi yang tidak diberi ASI 30\% lebih mungkin mengalami keterlambatan perkembangan untuk keterampilan motorik kasar. ${ }^{18}$ Bayi yang diberikan ASI eksklusif memiliki pertumbuhan dan perkembangan yang lebih baik karena melalui ASI, terjadi transfer perkembangan motorik balita. Pemberian ASI pada perkembangan kognitif bisa jadi dijelaskan oleh dua faktor. Salah satunya adalah adanya asam lemak tak jenuh ganda berantai panjang dan asam decosahexaenoic (DHA), yang penting untuk perkembangan otak. ${ }^{23}$

Karina $^{24}$ melaporkan bahwa ASI eksklusif memengaruhi perkembangan motorik, bayi yang diberikan ASI secara eksklusif memiliki pertumbuhan dan perkembangan motorik yang lebih baik. Sebaliknya, jika bayi tidak diberikan ASI eksklusif, bayi akan mengalami penurunan kecerdasan. Novita $\mathrm{dkk}^{25}$ melaporkan bahwa pemberian ASI tidak eksklusif memungkinkan 1,68 kali lebih besar bayi mempunyai IQ di bawah rata-rata. Bayi yang diberikan ASI eksklusif fungsi kognitifnya lebih baik dibandingkan dengan yang tidak ASI eksklusif. Pemberian ASI secara eksklusif harus diikuti dengan tindakan lain dalam upaya membuat tumbuh kembang baduta menjadi lebih baik, di antaranya pemberian stimulasi motorik dan status gizi. ${ }^{26}$

Hasil penelitian menunjukkan bahwa tidak terdapat hubungan antara status gizi dengan perkembangan motorik, tetapi anak dengan status gizi pendek berpeluang 2,45 kali mengalami perkembangan motorik menyimpang. Hal tersebut juga sejalan dengan penelitian Gunawan $\mathrm{dkk}^{27}$ yang melaporkan bahwa tidak terdapat hubungan antara gangguan perkembangan dengan status gizi. ${ }^{27}$ Sudfeld $\mathrm{dkk}^{28}$ melaporkan bahwa jika tidak terdapat hubungan antara status gizi dengan perkembangan motorik, bukan berarti status gizi tidak berpengaruh sama sekali. Banyak faktor yang dapat memengaruhi hal tersebut. ${ }^{28}$ Perkembangan motorik anak akan lebih maksimal bila didukung dengan integrasi lingkungan, pendidikan, dan intervensi stimulasi. ${ }^{10}$

Faktor lain yang menyebabkan tidak terdapat hubungan antara status gizi dengan perkembangan motorik baduta adalah asupan zat gizi baduta sehari-hari. Menurut Benton, ${ }^{29}$ beberapa zat gizi sangat berpengaruh terhadap perkembangan otak, di antaranya protein, energi, lemak tertentu, besi, seng, tembaga, yodium, selenium, vitamin A, kolin 
Dahliansyah dkk: Hubungan pemberian ASI eksklusif, status gizi dan kejadian diare dengan perkembangan motorik pada $1000 \mathrm{HPK}$

Tabel 2. Hubungan ASI eksklusif, status gizi, dan kejadian diare dengan perkembangan motorik

\begin{tabular}{lcccccccc}
\hline \multirow{2}{*}{ Variabel } & \multicolumn{2}{c}{ Sesuai } & \multicolumn{2}{c}{ Meyimpang } & \multicolumn{2}{c}{ Jumlah } & \multirow{2}{*}{$\mathrm{p}$} \\
\cline { 2 - 6 } & $\mathrm{n}$ & $\%$ & $\mathrm{n}$ & $\%$ & $\mathrm{n}$ & $\%$ & \\
\hline ASI eksklusif & 69 & 73,4 & 25 & 26,6 & 94 & 100 & \\
$\quad$ Ya & 24 & 55,5 & 20 & 45,5 & 44 & 100 & 0,028 & \\
$\quad$ Tidak & & & & & & & & \\
Status gizi & 68 & 64,8 & 37 & 35,2 & 105 & 100 & 0,240 \\
$\quad$ Normal & 25 & 75,8 & 8 & 24,2 & 33 & 100 & \\
$\quad$ Pendek & & & & & & & \\
Kejadian diare & 69 & 65,7 & 36 & 34,3 & 106 & 100 & 0,453 \\
$\quad$ Tidak & 24 & 72,7 & 9 & 27,3 & 33 & 100 & \\
$\quad$ Ya & & & & & & &
\end{tabular}

Sumber : Data Primer (2018)

Tabel 3. Analisis hubungan ASI eksklusif, status gizi, kejadian diare dengan perkembangan motorik

\begin{tabular}{|c|c|c|c|c|}
\hline \multirow{2}{*}{ Variabel } & \multirow{2}{*}{ OR } & \multicolumn{2}{|r|}{ IK95\% } & \multirow{2}{*}{$\mathrm{p}$} \\
\hline & & Lower & Upper & \\
\hline ASI eksklusif & 0,45 & 0,21 & 0,99 & 0,046 \\
\hline Status gizi $(\mathrm{TB} / \mathrm{U})$ & 2,45 & 0,86 & 6,98 & 0,093 \\
\hline Diare & 1,56 & 0,61 & 3,95 & 0,352 \\
\hline Constant & 0,39 & & & 0,323 \\
\hline
\end{tabular}

dan folat. Gibson $\mathrm{dkk}^{30}$ melaporkan bahwa praktik pemberian makan dan perilaku yang saling melengkapi sangat berpengaruh terhadap pertumbuhan sehingga pengaturan pemberian makanan sangat diperlukan. Menurut Rosidi dan Syamsianah, ${ }^{31}$ ukuran antropometri yang paling berpengaruh terhadap perkembangan motorik kasar balita adalah indeks TB/U dan IMT/U. Terdapat hubungan antara asupan protein dan riwayat penyakit infeksi terhadap indeks $z$-score $\mathrm{TB} / \mathrm{U}$ pada balita. ${ }^{32}$

Hasil penelitian menunjukkan berdasarkan recall yang dilakukan, rata-rata asupan konsumsi kurang, jika dibandingkan dengan angka kecukupan gizi (AKG) yang dianjurkan. Pentingnya pemberian makanan yang bergizi belum dipahami oleh para ibu dalam upaya meningkatkan status gizi baduta. Faktor pendidikan dan pekerjaan orang tua, pendidikan ibu yang rendah berisiko terhadap perkembangan anak yang terlambat. $\mathrm{Hal}$ tersebut disebabkan cara pemberian stimulasi perkembangan anak belum diketahui ibu serta pekerjaan tidak tetap yang memengaruhi pendapatan keluarga. ${ }^{27}$ Menurut Rosidi dan Syamsianah, ${ }^{31}$ salah satu faktor yang bisa diprediksi berhubungan dengan perkembangan motorik kasar balita adalah pendidikan ibu. Pekerjaan ayah dengan penghasilan yang tidak tetap juga dapat berdampak kepada sosial ekonomi yang kurang sehingga akan berpengaruh terhadap pengasuhan anak. ${ }^{33}$

Berdasarkan hasil penelitian didapat bahwa 50,7\% pendidikan ibu lebih banyak tidak tamat SMA/ sederajat. Sementara pekerjaan ayah, 51,4\% bekerja dan lainnya adalah pekerja swasta, buruh, maupun kerja borongan. Pendidikan dan pekerjaan orangtua kurang mendukung pemenuhan gizi baduta. Status gizi yang baik akan memengaruhi perkembangan motorik anak. Status gizi merupakan gambaran kondisi tumbuh kembang anak, baik masa lalu maupun masa sekarang. Anak baduta yang memiliki kecukupan gizi baik memiliki perkembangan motorik kasar yang lebih baik dibandingkan dengan gizi kurang maupun gizi buruk. ${ }^{27}$ Penelitian di Tanzania melaporkan bahwa kurang gizi kronis dan akut terkait dengan gangguan kognitif, komunikasi, dan perkembangan motorik pada bayi. ${ }^{10}$ Pada balita stunting telah terbukti dalam jangka 
panjang berdampak merugikan pada kemampuan kognitif setelah dewasa untuk mencapai pendidikan dan mendapatkan pekerjaan. ${ }^{34}$

Kami mendapatkan tidak terdapat hubungan antara kejadian diare dengan perkembangan motorik, tetapi anak yang menderita diare berpeluang 1,56 kali mengalami perkembangan motorik menyimpang. Beberapa penelitian melaporkan terdapat pengaruh kejadian diare pada balita dengan perkembangan motorik. Kvestad dkk ${ }^{35}$ melaporkan bahwa diare merupakan faktor risiko tambahan untuk perkembangan saraf yang buruk pada anak yang rentan. Dengan demikian, stimulasi anak dini dan zat gizi umum untuk perkembangan anak penting dilakukan. Isda $\mathrm{dkk}^{36}$ melaporkan bahwa terdapat pengaruh diare terhadap kejadian malnutrisi pada balita di Puskesmas Batoh tahun 2015. Balita dengan riwayat diare berisiko 10,00 kali untuk masuk ke dalam kriteria gizi kurang (malnutrisi). ${ }^{36}$ Pati $\mathrm{dkk}^{37}$ melaporkan tidak terdapat hubungan antara peran ibu dengan durasi diare akut anak selama perawatan. ${ }^{37}$

Pada penelitian kami tidak terdapat hubungan antara kejadian diare dengan perkembangan motorik. Berdasarkan data hasil penelitian dari 138 responden, 33 (24\%) menderita diare, serta $9(27,3 \%)$ menderita diare dan motorik menyimpang baduta. Dengan demikian, berdasarkan sebaran data sangat tidak proposional karena responden yang tidak menderita diare dan tidak mengalami penyimpangan perkembangan motorik lebih banyak.

Subjek yang mendapatkan ASI selama 6 bulan dari 138 baduta, 94 (68,1\%), sedangkan yang mengalami perkembangan motorik sesuai $73,4 \%$. Baduta terlindungi terhadap infeksi karena ASI mengandung imunoglobulin. ${ }^{2,38}$ Rahmadhani $\mathrm{dkk}^{39}$ melaporkan bahwa pemberian ASI eksklusif selama 6 bulan berhubungan dengan angka kejadian diare akut. Hal tersebut menunjukkan bahwa pemberian ASI eksklusif sangat berperan dalam membantu memberikan perlindungan sistem cerna sehingga tidak berdampak pada perkembangan motorik baduta.

Kandungan ASI adalah $40 \%$ protein kasein dan $60 \%$ whey. Whey berfungsi untuk melindungi dari infeksi. Kandungan bakteri baik (L. Bifidus) dalam ASI membuat suasana asam dalam saluran cerna sehingga menghambat pertumbuhan bakteri patogen. ${ }^{40}$ Bayi yang mendapat ASI eksklusif telah terbukti lebih rendah terkena infeksi pernapasan akut dan diare, dibandingkan dengan yang tidak ASI. ${ }^{41}$
Faktor lain yang memengaruhi kejadian diare dengan perkembangan motorik, yaitu pemberian makanan pendamping ASI (MP-ASI). Pemberian makanan pertama kali kepada bayi setelah ASI selama 6 bulan merupakan masa paling berbahaya. Risiko terjadinya infeksi lebih lanjut, terutama penyakit diare yang diakibatkan makanan tidak sesuai umur dan jenisnya. ${ }^{38}$ Riwayat diare yang diderita baduta dapat menyebabkan malnutrisi sebagai akibat penurunan pertahanan mukosa usus. Infeksi pada usus dapat memengaruhi status gizi melalui penurunan asupan makanan dan absorpsi usus sehingga menggangu sintesa jaringan dan perkembangan anak. ${ }^{36}$

Hasil recall 24 jam menunjukkan semua baduta telah mendapatkan MP-ASI dan makanan yang diberikan dapat diterima. Hal tersebut dibuktikan dengan kejadian diare yang rendah, yaitu 33 (23,9\%). Pemberian MP-ASI yang adekuat dapat memenuhi kebutuhan gizi bayi sehingga pertumbuhan dan perkembangan motorik berkembang secara normal. Selain itu dapat pula merangsang rasa percaya diri dan keterampilan makan bayi. ${ }^{42}$

Kebiasaan mencuci tangan sebelum makan atau sebelum balita diberikan makanan sangat memengaruhi kejadian diare. Hasil penelitian yang dilakukan di India melaporkan peningkatan kondisi sanitasi dan perilaku hygiene berhubungan dengan kejadian stunting pada bayi usia $0-23$ bulan. ${ }^{44}$ Sanitasi yang buruk dan faktor kebiasaan mencuci tangan menjadi kontributor risiko diare pada anak balita. Hal tersebut dapat menunjukkan titik intervensi yang penting dalam pengurangan tingkat diare yang terjadi pada anak di bawah 5 tahun. ${ }^{45}$ Hasil penelitian kami menujukkan bahwa hampir $78,3 \%$ responden mencuci tangan sebelum makan sehingga dapat menekan kejadian diare.

Bukti empiris menunjukkan bahwa mencuci tangan dengan sabun mengurangi risiko terjadinya diare, infeksi saluran pernafasan, dan transmisi cacing tanah. ${ }^{46}$ Aktivitas bayi yang bersinggungan secara langsung pada benda di lingkungan sekitarnya dapat meningkatkan risiko terjadinya diare. ${ }^{44}$

Perubahan fungsi usus kecil di awal masa bayi, disebabkan diare di negara berkembang semakin sering terjadi, disertai dengan arsitektur mukosa berubah, termasuk mengurangi massa enterocyte dan bukti aktivasi kekebalan dan peradangan pada mukosa. Perubahan ini tampaknya merupakan hasil dari 
faktor alam yang dapat menjadi penyebab gangguan pertumbuhan, dan kejadian stunting pada anak. ${ }^{17}$

Keterbatasan penelitian kami adalah data ASI eksklusif yang lemah karena perbedaan persepsi tentang definisi ASI eksklusif antara teori dan pemahaman masyarakat. Selain itu, data yang bersumber dari KMS sangat rendah karena kebanyakan data ASI eksklusif diisi kader Posyandu bukan petugas kesehatan. Data kejadian diare yang diperoleh hanya melihat 3 bulan terakhir, yang mungkin belum bisa mewakili kejadian diare sebenarnya. Sementara data perkembangan motorik kasar dan halus yang diperoleh melalui kuesioner KPSP memiliki kelemahan. Hal tersebut disebabkan aktifitas anak terbatas di lokasi penelitian karena sarana dan prasarana yang mendukung pengamatan tersebut terbatas sehingga banyak kemampuan motorik yang tidak bisa dilakukan oleh subyek penelitian.

\section{Kesimpulan}

Terdapat hubungan antara pemberian ASI eksklusif selama periode 1000 HPK dengan perkembangan motorik baduta. Sementara antara status gizi dengan perkembangan motorik baduta tidak terdapat hubungan. Demikian pula tidak terdapat hubungan antara kejadian diare dengan perkembangan motorik baduta. Hasil analisis multivariat menunjukkan bahwa baduta ( $\geq 6-24)$ bulan yang tidak diberi ASI eksklusif berisiko 0,45 kali mengalami gangguan perkembangan motorik. Dengan demikian pemberian ASI eksklusif sangat memengaruhi perkembangan motorik, sehingga sangat tepat jika pengawasan pemberian ASI eksklusif selama periode $1000 \mathrm{HPK}$ perlu ditingkatkan lagi.

\section{Ucapan terima kasih}

- Dr. Yulia Lanti Retno Dewi, dr, M.Si, dan Dr. dr. Eti Poncorini Pamungkasari, M.Pd, selaku Penguji Tesis, yang telah bersedia memberikan masukan dan saran k perbaikan.

- Pusat Peningkatan Mutu SDM Kesehatan, Badan Pengembangan dan Pemberdayaan SDM Kesehatan Kementerian Kesehatan, sebagai pemberi bantuan pembiayan pendidikan.

\section{Daftar pustaka}

1. Cai X, Wardlaw T Brown DW, Global trends in exclusive breastfeeding Int Breastfeeding J 2012;7:12.

2. Victora CG, Bahl R., Barros AJD, dkk. For The Lancet Breastfeeding Series Group, Breastfeeding in the 21st century: epidemiology, mechanisms, and lifelong effect, Lancet 2016; 387:475-90.

3. Gandy JW, Madden A, Holdsworth. Gizi dan dietetik. Jakarta: EGC, 2012.

4. Kementerian Kesehatan Republik Indonesia. Pedoman Pekan ASI Sedunia. Direktorat Gizi Masyarakat. Jakarta, 2016.

5. Laporan Riset Kesehatan Dasar (RISKESDAS) Badan Penelitian dan Pengembangan Kesehatan Kementerian Kesehatan RI Tahun 2013.

6. Dinkes Propinsi Kalimantan Barat. Profil Dinas Kesehatan Kalimantan Barat tahun 2016.

7. Dinkes Kota Pontianak. Profil Dinas Kesehatan Kota Pontianak tahun 2016.

8. Aritonang I. Menilai kadar: pengetahuan, sikap, dan praktik gizi seimbang untuk sehat optimal. Yogyakarta: Leutiakbook dengan CEBlos; 2013.

9. Triyani S, Meilan N, Purbowati N. Hubungan antara lama pemberian ASI eksklusif dengan perkembangan anak usia 12 36 bulan. Jurnal Ilmu dan Teknologi Kesehatan 2014;1:113-9.

10. Lassi ZS, Das JK, Zahid G, Imdad A, Bhutta ZA. Impact of education and provision of complementary feeding on growth and morbidity in children less than 2 years of age in developing countries: a systematic review, BMC Public Health 2013;13:S13.doi:10.1186/1471-2458-13-S3-S13.

11. Kemenkes Republik Indonesia. Pokok- pokok peraturan pemerintah no. 33 tahun 2012 tentang pemberian air susu ibu eksklusif. Jakarta: Kemenkes; 2012.

12. Nur A, Marissa, N. Riwayat pemberian air susu ibu dengan penyakit infeksi pada balita. Jurnal Kesehatan Masyarakat Nasional 2014;9:144-9.

13. Engebretsen IMS, Jackson D, Fadnes LT, Growth effects of exclusive breastfeeding promotion by peer counsellor in subSaharan Africa: the cluster-randomised PROMISE EBF trial. BMC Pub Health 2014;14:633.https:/doi.org/10.1186/14712458-14-633.

14. Keusch GT, Rosenberg IH, Denno DM, dkk. Implications of acquired environmental enteric dysfunction for growth and stunting in infants and children living in low- and middleincome countries. Review: Food Nutr Bull 2013;34:357-64.

15. Kemkokesra Republik Indonesia. Kerangka kebijakan gerakan nasional percepatan perbaikan gizi dalam rangka seribu hari pertama kehidupan (Gerakan $1000 \mathrm{HPK})$. Indonesia tahun 2013. Jakarta: Kemkokesra RI; 2013. 
Dahliansyah dkk: Hubungan pemberian ASI eksklusif, status gizi dan kejadian diare dengan perkembangan motorik pada $1000 \mathrm{HPK}$

16. Achadi EL. Periode kritis 1000 hari pertama kehidupan dan dampak jangka panjang terhadap kesehatan dan fungsinya. Kursus penyengar ilmu gizi PERSAGI. Yogyakarta: lecture given 2014 November 25. Departemen Gizi Kesmas: FKM UI; 2014.

17. USAID. Multi-sectoral nutrition strategy 2014-2025, technical guidance brief, the 1.000-day window of Opportunity.USAID; 2015.

18. Ali SS, Dhaded, Goudar S. The impact of nutrition on child development at 3 years in a rural community of India. Int J Prev Med 2014;5:494-9.

19. Sugeng T, Nessi M, Niken P. Hubungan antara lama pemberian ASI eksklusif dengan perkembangan anak usia 12 - 36 bulan. Jurnal Ilmu dan Teknologi Kesehatan 2014;1:113-9.

20. Alberto UT, Patrizia B, Tarantino V, dkk. Effect of duration of breastfeeding on neuropsychological development at 10 to 12 years of age in a cohort of healthy children, Develop Med \& Child Neurol 2012;54:843-8.

21. Proverawati A, Asfuah S. Buku ajar gizi untuk kebidanan. Yogyakarta: Nuha Medika; 2009.

22. Lanigan JA, Bishop J, Kimber AC, Morgan J. Systematic review: concerning the age of introduction of complementary foods to the healthy full-term infant. Eur J Clin Nutr 2001;55:309-20.

23. Tasnim S. Effect of breast feeding on child development: At birth and beyond. Review: South East Asia J Pub Health 2014;4:4-8.

24. Karina. ASI sebagai pilihan untuk perbaiki perkembangan motorik bayi. Majority 2015;4:7.

25. Novita L, Gurnida LD, Garna H. Perbandingan fungsi kognitif bayi usia 6 bulan yang mendapat dan yang tidak mendapat ASI eksklusif. Sari Pediatri 2008; 9:6:429-34.

26. Kusuma IR, Salimo H, Sulaeman ES. Analisis pengaruh berat badan lahir rendah, pemberian ASI eksklusif, stimulasi dan status gizi terhadap perkembangan motorik kasar anak usia 6-24 bulan di Kabupaten Banyumas, Prosiding Seminar Nasional Kebidanan 2017;1:321-7.

27. Gunawan G, Fadlyana E, Rusmil K. Hubungan status gizi dan perkembangan anak usia 1-2 tahun. Sari Pediatri 2011;13:142-6.

28. Sudfeld CR, McCoy DC, Danaei G, Fink G, Ezzati M, Andrews KG, dkk. linear growth and child development in low- and middle-income countries: a meta-analysis. Pediatrics 2015;135:e1266-75.

29. Benton D. The influence of dietary status on the cognitive performance of children. Mol Nutr Food Res 2010;54: 457-70.

30. Gibson RS, Abebe Y, Hambidge KM, Arbide I, Teshome A, Stoecker BJ. Inadequate feeding practices and impaired growth among children from subsistence farming households in Sidama, Southern Ethiopia. Matern Child Nutr 2010;5:260-
75

31. Rosidi A, Syamsianah A. Optimalisasi perkembangan motorik kasar dan ukuran antropometri anak balita di Posyandu "Balitaku Sayang” Kelurahan Jangli Kecamatan Tembalang Kota Semarang. Diakses pada 24 Juli 2017. Diunduh dari: httpl/jurnal.unimus.ac.id.

32. Sundari E, Nuryanto N. Hubungan asupan protein, seng, zat besi, dan riwayat penyakit infeksi dengan z-score TB/U pada balita. J Nutr Coll 2016; 5:521-9.

33. Suryaputri LY, Rosha BC, Anggraeni D. Determinan kemampuan motorik anak berusia 2-5 tahun: studi kasus di Kelurahan Kebon Kalapa Bogor. Penel Gizi Makan 2014; 37: 43-50.

34. Susan PW, Susan MC, Amika W, Clive O, Sally MGM. Early childhood stunting is associated with lower developmental levels in the subsequent generation of children. J Nutr 2015;145: 823-828.

35. Kvestad I, Taneja S, Hysing M, Kumar T, Bhandari N, Strand TA. Diarrhea, Stimulation and growth predict neurodevelopment in young North Indian children. Plos One 2015;10:1-13.

36. Isda M, Rinanda T, Suhanda R. Pengaruh diare terhadap malnutrisi pada balita di Puskesmas Batoh Banda Aceh tahun 2015, Sari Pediatri 2015;18:50-4.

37. Pati GP, Ninung RDK, Hartantyo I, Soemantri AG. Peran ibu terhadap durasi diare akut anak umur 6-24 bulan selama perawatan. Sari Pediatri 2013;15:56-60.

38. Andriani M, Wirjatmadi B, Peranan gizi dalam siklus kehidupan. Edisi ke 2, Jakarta: Kencana Prenadamedia Group; 2014.

39. Rahmadhani EP, Lubis G, Edison. Hubungan pemberian ASI eksklusif dengan angka kejadian diare akut pada bayi usia 0-1 tahun di Puskesmas Kuranji Kota Padang. Jurnal Kesehatan Andalas 2013 2:62-6.

40. Susetyowati. Gizi bayi dan balita, dalam ilmu gizi teori dan aplikasi. Jakarta: EGC; 2016.

41. Sonko A, Worku A. Prevalence and predictors of exclusive breastfeeding for the first six months of life among women in Halaba special woreda, Southern Nations, Nationalities and Peoples' Region/SNNPR/, Ethiopia: a community based cross-sectional study. Arch Pub Health 2015;73:53.

42. Yogi ED. Pengaruh pola pemberian asi dan pola makanan pendamping ASI terhadap status gizi bayi usia 6-12 bulan. Jurnal Delima Harapan 2014;2:14-8.

43. Tambe A, Nzefa L, Nicoline N. Childhood diarrhea determinants in Sub-Saharan Africa: a cross sectional study of Tiko-Cameroon. Challenges 2015;6:229-43.

44. Rah JH, Cronin AA, Badgaiyan B, Aguayo VM, Coates $S$, Ahmed S. Household sanitation and personal hygiene 
Dahliansyah dkk: Hubungan pemberian ASI eksklusif, status gizi dan kejadian diare dengan perkembangan motorik pada 1000 HPK

practices are associated with child stunting in rural India: a cross-sectional analysis of surveys. BMJ Open 2015;5:1-10.

45. Gorham TJ, Yoo J, Garabed R, Mouhaman A, Lee J. Water access, sanitation, and hygiene conditions and health outcomes among two settlement types in rural far North Cameroon. Res
Pub Health 2017;14:441:1-12.

46. Hirai M, Graham JP, Mattson KD, Kelsey A, Mukherji S, Cronin AA. Exploring determinants of handwashing with soap in Indonesia: a quantitative analysis. Res Pub Health 2016;13:868:1-15. 